\title{
PLANNING ACTIVITIES IN COASTAL AREAS ITALIAN AND CROSS-BORDER APPROACHES ALONG THE ADRIATIC SEA
}

\author{
DONATELLA CIALDEA \\ L.a.co.s.t.a. Laboratory (Laboratory for the activities related to the territorial and environmental development) \\ University of Molise, Via De Sanctis 86100 Campobasso, ITALY.
}

\begin{abstract}
Coastal areas are the typical 'critical zones' for the planning activities. This paper illustrates the results realised by the L.a.co.s.t.a. Laboratory of the University of Molise in Italy, in order to compare the analysis of urban and territorial planning processes in force in Italy and in its Cross-border Countries along the Adriatic Sea. The work has examined the historical evolution of the laws and norms relating to the landscape protection in different situations, with particular attention to those preserving the landscape values in harmony with the territorial plans, to contrast the growing anthropic development especially along the coastal zones. The aim of our research is to define the different levels of territorial survey and develop a basic cartography for the countries involved in our survey so as to assure the validity of the methodology used in analysing the territory by taking into account the diverse territorial conditions of each country.
\end{abstract}

Keywords: coastal zones, landscape, planning.

\section{INTRODUCTION}

This paper contains the results of the international comparative studies in planning activities related to the coastal areas along the Adriatic Sea, which have been undertaken during the recent years by the L.a.co.s.t.a. Laboratory of the University of Molise, as part of the projects financed by the Interreg IIIA Programme Adriatic Cross Border ('Sustainable Development of Coastal Areas') and by the NPPA Neighbourhood Programmes INTERREG/CARDSPHARE ("Archaeological and Environmental Sites") whose Scientific Director was Prof. Donatella Cialdea.

The approach to planning activities it not the same in the countries that were examined : in fact it is very different in Italy and in the Cross-Border Countries. Italian processes aim to unify the concepts of 'urban' and 'landscape' approaches, that traditionally followed different planning and legislative schemes. In the Balkan States, the planning processes derive from a historical and political context profoundly marked by events from 1991 till date. The main laws of land-use planning were drawn up after 1991, ex novo or as replacements for existing ones, proposing a totally different system from the previous one, where existing.

Our work was carried out by developing a detailed analysis of the policies for the planning activities control and analyszing some typical situations along the coastal areas of which, as noted, diverse countries with different planning policies overlook. The analysed examples concern, in particular, the central part of the Adriatic coast: the Italian side is represented by the Molise Region while for the Cross-border coasts the Croatian and the Albanian cases are involved. In fact, these countries were partners in some recent projects carried out on already mentioned EU funds by the L.a.co.s.t.a Laboratory. 


\section{THE URBAN AND LANDSCAPE POLICIES}

The Italian planning system began in a historical and temporal context that is very different from that of Croatia and Albania, and is the result of a stratification of plans and regulations from the 1940s till today.

In fact, in Italy, the legislative framework was for the first time organized in the still enforced Urban General Law No. 1150 of 1942, which has been changed or revised through the years. Despite the wealth of laws produced in this sector, both in quantity and in quality, the results on the territory are not what were expected. The attention that was given to 'landscape' and 'cultural heritage' protection from the 1930s contributed to the enlargement of the Italian legislative framework that is formed by complete and extended laws (Law No. 1089 and Law No. 1497 of 1939 and Law No. 431 of 1985) not always well interpreted and put into act by Local and Regional Administrations. The orientation and 'identification of the policy for national territorial organization' are currently under the National Government jurisdiction but it has no powers to actually draw up Urban Plans. From 1998 Provinces - which contain some Municipalities - must draw up a General Plan of the Province's Territory that should deal with the various territorial planning themes without excluding the landscape and the environment. These plans should be able to fill the gaps caused by Regional Plans, scheduled by the Urban General Law of 1942 and never enacted by administrations in charge.

It is also important to underline the aim of linking, within the Provincial Plans, the 'urban' and 'landscape' themes that traditionally followed different legislative and planning rules. The Galasso Law (the already mentioned Law No. 431/1985) delegated landscape conservation to a specific 'Vast Area Landscape Environmental Plan', which had started out as sectorial plans but often became the only planning tool above the municipal level. The General Plan of the Province's Territory should comply with the Landscape Plans where they exist, and, regarding landscape conservation, fill the planning gaps in the territory, which have been caused by the absence of landscape plans. There is a problem in the coordination between landscape planning and physical planning but mainly between the General Plan of the Province's Territory and the existing sectorial plans. The stratification of plans which overlap at different levels, often approved whilst the Urban Plans are still in force, causes a situation that is complex and difficult to interpret. The drawing up of sectorial plans contributes to the creation of conflicts and contradictions between the different planning tools and doubt about the interpretation of the plans and their activation on the territory. Italy's physical and urban planning system is characterised by a surplus of laws and plans that, aiming to deepen the knowledge of every aspect of territorial management, causes many difficulties for their application and for management of realization times [1-8].

In the Balkan States, 1991 can be seen as a turning point in the history of these countries: in that year, Croatia declared its independence from the Federation, while in Albania, the Parliamentary Democracy replaced the Socialist Government of Enver Hoxha. Moreover, in Croatia and in Albania, in parallel to the consolidation of the Republic, the decentralization of administrative functions from Central Government to Local Government Units occurred with the consequent delegation of planning activities. The first laws for land-use planning were, therefore, drawn up after 1991, proposing a system totally different from the previous one. The territorial analysis conducted on the countries in the case studies reveals that the increasing anthropic use mostly concerns coastal areas, leaving almost or entirely unchanged the inland areas, with the exception of the areas of the capital, Zagreb or Tirana. As a result of this non-regulated urban development suffered by the two Balkan Countries, their spatial planning systems are forced to deal with the increasing development within the territory, 
trying to shorten as much as possible the time necessary for the implementation of these plans. This need is even more evident in Albania, where the processes of formation and implementation of plans are often very long, thus contributing to the extension of the phenomena of illegal building [9-11].

In particular, in Croatia, the process of the decentralisation of state power began in the early 1990s and became one of the fundamental elements in the democratisation of the State. Currently, the subdivision of administrative and decisional competences is established by the law on local and regional autonomy ('Official Gazette' n. 33/2001), which identifies two levels of government units below that of the state. The first unit is the county: within the county, power is divided between two other local government units, namely, cities and municipalities, which represent a grouping of territories, on the basis of the number of inhabitants. A municipality is constituted by groupings of settlements which together reach a total of 10,000 inhabitants: groupings of over 10,000 inhabitants constitute a city. However, despite the existence of a political division with so many branches, the country has a joint territorial plan to which the individual plans of the counties, cities and municipalities must refer [12-14]. During the process of decentralisation, the territorial planning system was updated and improved in order to respond to new needs and within the space of 10 years all counties had their own territorial plan based upon the principles laid down by the central government. The Croatian Republic Territorial Planning Strategy, the text which forms the basis of the entire Croatian planning system, was drawn up and approved in 1997, in conformity with the Territorial Planning Law of 1994. This very important document, drawn up at the end of the civil war, made a realistic analysis of the situation in post-war Croatia and provided the foundations for all future planning throughout the Republic. Territorial planning must, therefore, valorise the presence of the natural resources which, although not many in number, constitute a patrimony of great value for the diversity and quality which characterise them. However, a territorial management system must also take into account not just the strengths but also their weaknesses In fact, the strategy also highlights the main problems afflicting the country, which constitute a menace for future sustainable development. The key texts kept in the library together with the law on territorial planning ('Official Gazette' n. 30/94, 68/98, 61/00, 32/02 and 100/04) establish the level of territorial planning levels and the types of obligatory plans for the counties, cities and municipalities: 1. County territorial plans; 2. Territorial plans in areas with particular characteristics; 3 . Territorial plans for cities and municipalities; 4. General urban plans; 5 . Local urban plans; 6. Detailed plans. The landscape is one of the elements protected by the territorial plan, which dedicates a specific article to the subject at the end of the norms attached to the plan entitled 'Protection measures for landscape values'.

In Albania the territorial management was in the hands of two specific bodies, one at the state level, the Council for Territorial Management, and one at the local level, the District Council. The latter was abolished following the decentralisation of functions to Local Government Units which were organised by Law No. 8653 of the 31/07/00 'Territorial-administrative division of local government units in the Albanian Republic'. The first level remains that defined as 'Communes and Municipalities', that is the local government base units which both have the same competences and authority. The only difference between a commune and a municipality derives from the fact that the first acts in rural areas and the second in urban areas. The second level was introduced by the law of 2000 and is defined as 'Region'. This represents a territorial and administrative unit comprising several Communes and Municipalities with the same interests, the same geographical, traditional, economic and social characteristics. 
The border of the Region coincides with that of the Cities and Municipalities which fall within $i t$. The regions are divided into districts. The territorial planning system was updated, in parallel to the decentralisation process described above, by the Urban Planning Law No. 8405 of the $17 / 09 / 1998$. According to the present law on urban planning a 'Regional Urban Planning Study' is a complex urban study, which includes the territory of one or more municipalities or districts; a 'General Plan' is an urban planning study of a specific aspect, which includes the entire national territory or its parts; an 'Environmental Study' is that which determines the ecological conditions or situation of a given area; a 'General Planning Scheme' is a complex urban planning study of a limited area and includes an examination of the prospects for expansion of a city's territory and the suburban zones of a village, settlement or centre for accommodation, industry and so on; and a 'Partial Urban Planning study' is a detailed study based on the forecast of a general town planning scheme, and includes parts of the territory where regulated actions are foreseen.

In contrast to the general picture of coastal management, several important planning and protection operations have been undertaken in areas of particular environmental value. Coastal management plans have been drawn up for these areas and in some cases zoning of the park or protected area has been approved. Moreover, Albania's remaining coastal areas are protected by a decision of the Council of Ministers No. 321 of the 20/07/92 which defined a Protected Coastal Strip that extends along the entire Albanian coastline and is denominated the 'vija kufizuese bredgetare', that is the 'red line'. The 'line' runs at a distance of $300 \mathrm{~m}$ from the coast, at $150 \mathrm{~m}$ from river banks and $200 \mathrm{~m}$ from historical and archaeological sites. In the areas delimited by this line every operation is subject to the approval of the Council for Territorial Planning (KRT).

Moreover, both Croatia and Albania are areas rich in environmental values. In particular, in Croatia the numerous islands that characterise the country form an environmental patrimony of considerable importance, safeguarded through the instrument of protected areas and through the implementation of the Nature 2000 Network. There are also sites of international interest such as Ramsar areas and a MAB Reserve. Despite the rapid building development, the Albanian coasts are still rich in uncontaminated naturalistic values between beaches and lagoons that outline a very articulated coast. Even along the Albanian coast there are numerous Ramsar areas and the Government is taking steps towards drafting a list of areas for inclusion in the Nature 2000 Network. Moreover, the aim of this paper is related to underline in our case-study the presence of interesting natural features that have been described in order to extend our territorial methodology to the Cross-Border Countries.

\section{THE COMPARATIVE TERRITORIAL ANALYSES}

A methodology to compare territorial analyses, drawn up by L.a.co.s.t.a. in recent years, was expanded on the systems based on the territorial planning of the Balkan Countries. It is based on the quality landscape aims researching, in order to provide useful contributions about 'measures for the protection of landscape values'.

The identification of quality landscape aims is a methodology for setting up territorial studies which can aid decision making on the part of local agencies as regards planning in the coastal zone; therefore, the territories analysed are the coastal areas belonging to the countries involved in the project. Therefore, in the first instance material was sought out which would permit a homogeneous reading of the territory in all three countries. It is obvious that the analysis of diverse entities requires the use of uniform tools, as far as possible standardised and known (Fig. 1). The study areas, where the territorial analysis was undertaken, were 


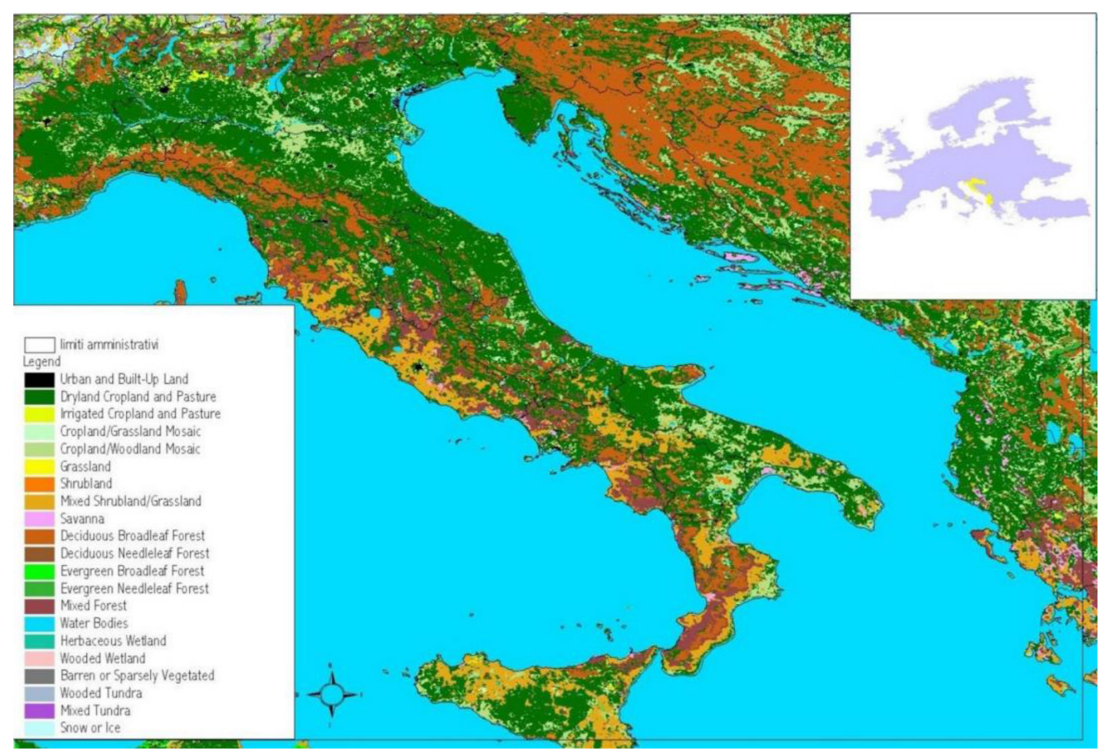

Figure 1: The Land Use Map with the unified legend.

Source: DIVA Processing in ArcGis by 1.a.co.s.t.a. Lab.

chosen on the basis of two parameters: 1 . coastal conditions and 2. the presence of environmental value areas.

The coastal sample areas are very different. The Croatian coast, rich in natural and cultural features - some of which are recognised as world heritage sites by UNESCO, presents a very varied situation from an orographic point of view. Often high and rocky, in other tracts the coast is flat. Really interesting are the mouths of the rivers Cetina and Neretva. These are areas in which there is heavy anthropological pressure - also linked with beach tourism - and the widespread presence of natural environments of great value.

The Albanian coast is characterised in the northern part by flat areas of alluvial origin with marshy zones and lagoons between the river mouths; several of which are recognised as wetlands under the Ramsar Convention. In contrast, the south coast is mainly high and rocky. There are two interesting areas: the lagoons of Karavasta and Butrint close to which there are important archaeological sites.

In Italy we have a different condition: the coast is flat and the major communication infrastructures (state road, motorway and railway) run along the Italian Adriatic coast, especially in the Molise Region, together with the widespread presence of structures used in the summer.

Moreover, in these sample areas we have conducted our research and applied our methodology: Our elementary data were collected and divided according to the five Resource Systems. They are: Physical-Environmental Resources System; Landscape-Visual Resources System; Historical-Cultural Resources System; Agricultural-Productive Resources System: Demographic-Tourism Resources System (Fig. 2a). In some cases, the data was extrapolated from maps and is usable in the form of shape files with polygons characterised by attributes that are easily transformable into grids; in other cases, the data is of numeric type (shape files) but is formed by data points (and diffusion algorithms have been elaborated for each individual 
case); in yet other cases, the data was provided by the local administration (and for each case disgregation algorithms have been found for the creation of grids containing information useful for research purposes).

The data for each system is processed in three chosen states, these are the Present State; the State evolved over time; and the Previsional State, that is with reference to the formulation of urban planning tools currently in use. Therefore, three basic grids were created, which serve as a reference for the reading of each resource system. They were constructed starting from several primary documents. The term basic grid defines the layers constituting the information base of the management system for the territorial data, which is useful for landscape analysis. Comparisons between the basic grids of each resource system will create the information and evaluations which will form the research conclusions (Fig. 2b).

To create the grids the raster data model was applied; precisely because the data derives from various sources and is unhomogeneous (from traditional map data to that in GIS format,
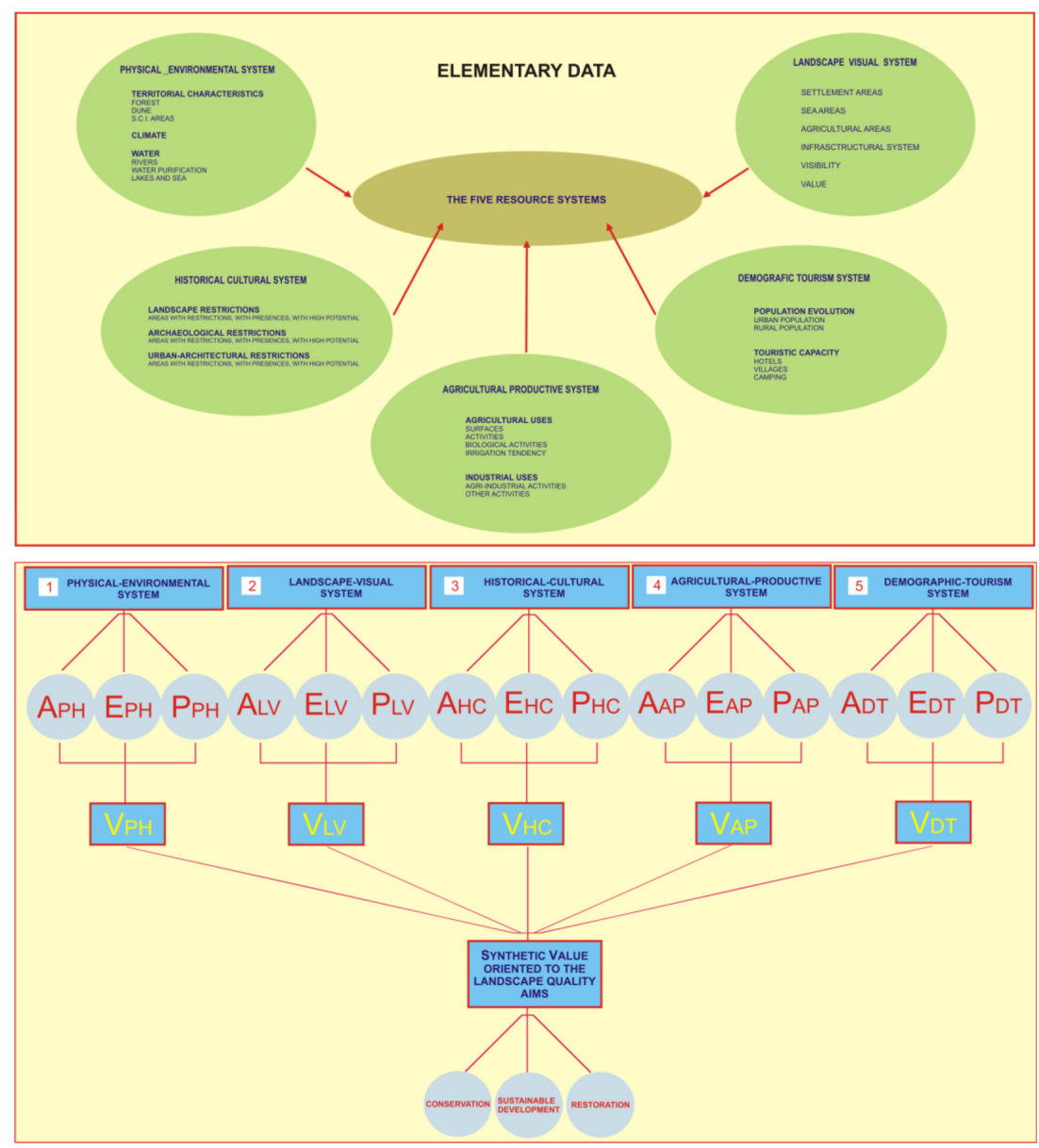

Figure 2: (a) Diagram showing data collection. Source: Our elaboration (b) From the systems to the evaluation. Source: Our elaboration. 
with different levels of geo-referencing from the lowest level to data shape points), the raster model is the least approximate for this type of application. As is known, the two main systems for modelling the real world in GIS are the raster model and the vector model. An extremely concise description of the specifications of each model in relation to the type of data to be processed is that the vector model suits discrete data, for example administrative boundaries, the limits of an urban planning zone, the electricity lines and data shape points, but is not good for representing data of a continuous nature such as the altimetrical model of a territory, the influence of a data shape point on the surrounding territory and distribution models in general because such phenomena do not have precise boundaries without any breaks. Moreover, the raster model facilitates intersection analysis with data of diverse accuracy because the accuracy is defined (knowingly by whoever conducts the analysis) by the size of the data cell used (and, therefore, by the accuracy established for the model) and not by the accuracy of the data collection.

An evaluation was assigned regarding the importance of each single element for each of the above mentioned categories; this evaluation is known as a value and may vary in a domain given by the following scale of ordinal type points: Low; Medium; High; Exceptional. In this form the synthesised maps were digitalised for the purposes of the project thus obtaining layers of vector information divided into the above categories and by different primitive graphic representations (point, line or polygon). Although the importance of the information contained in the layer regarding geological instability was recognised, the decision was taken during the construction of the basic raster, to omit the elements it contained. This choice was motivated by the obvious difference in the nature of the information in this layer; in fact, it does not present a positive value but a negative one. Therefore, the following four raster were obtained, one for each category of interest: Historic; Agricultural; Naturalistic; Visual.

The study wanted to take a close look at the aspects of planning in coastal areas, which are particularly interesting from an environmental point of view. For Croatia we analysed the area of the Neretva River Delta, south of Split, and, for Albania, the area of the Karavasta Lagoon, south of the port of Durres. We have chosen these two cross-border areas as they have several aspects in common: both are areas included in the Ramsar Convention List, both are coastal areas and, in particular, both are situated in an agricultural productive context.

We aimed to analyse these sites, because of their naturalistic importance and also because of the attention paid to planning tools to support their protection (Fig. 3). Moreover, the conditions of the coastal area in the Molise Region are different: it has numerous natural areas classified as Sites of Community Importance - which are located along the mouths of major rivers and along the coast and where there are residual sand dunes - but there are no Ramsar areas. They are also inserted in a typically agricultural context, for which specific planning norms are totally lacking.

As regards the geological characteristics on both sides there are soils of the same age although the more recent land typical of the Italian coastline is totally missing on the Balkan coasts. This difference creates totally different geographical features along the two coast lines. The western coast is mainly linear and flat with sandy beaches, with the exception of some promontories. This geographical shape is defined by the land's geology, which is mostly clay deposits and sandstones, as well as by the presence of surface runoff that brings sediment and detritus material along the coast. The eastern coast, in the section between the Gulf of Trieste and the border between Montenegro and Albania, on the other hand, is characterised by a very indented coastline flanked by numerous islands that run parallel to the coast [15-19]. This shape is defined by the mainly karstic nature of the coastal region, where, for several hundreds 


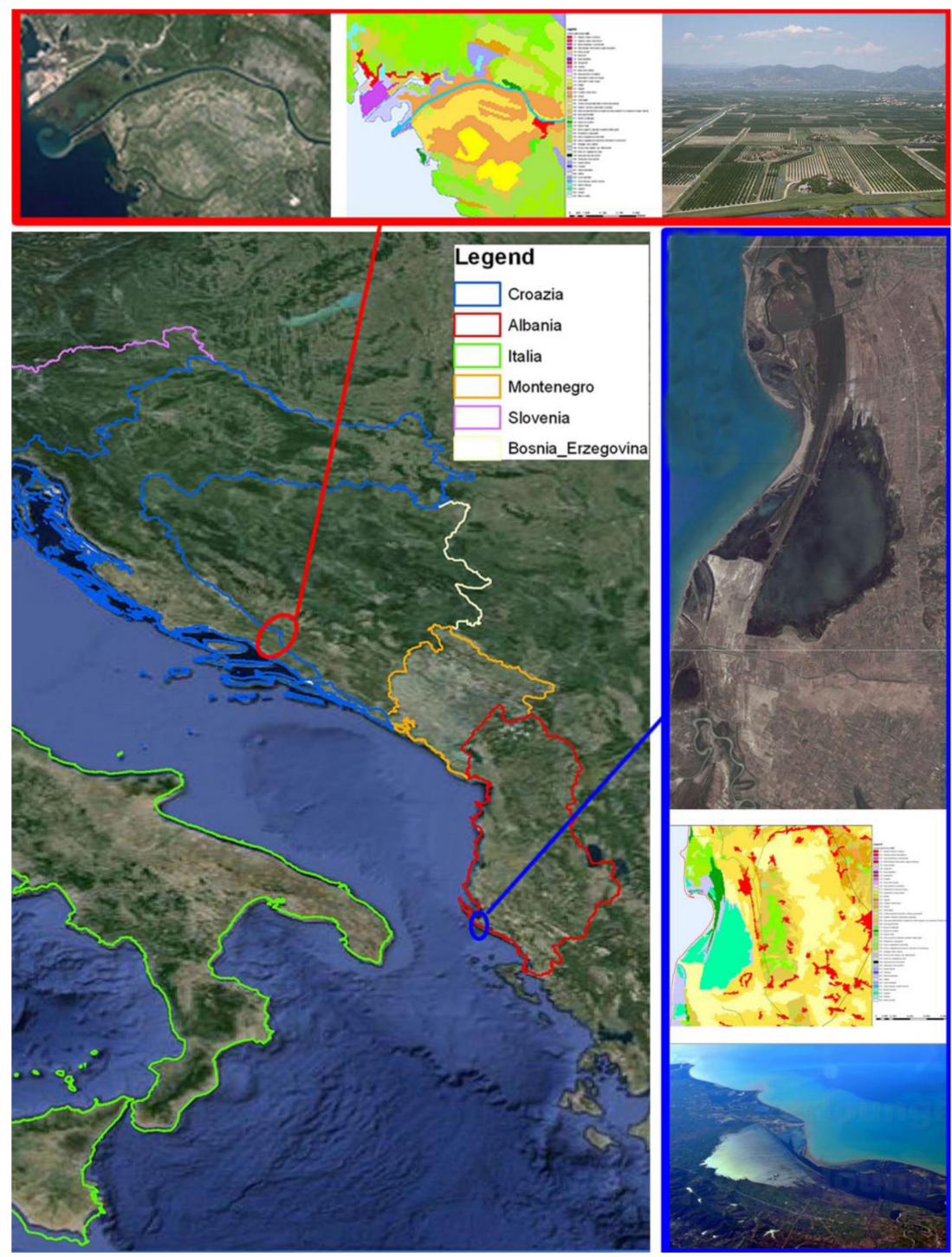

Figure 3: The sample areas. Source: Processing in ArcGis by l.a.co.s.t.a. Lab.

kilometres, there are rivers carrying alluvial sediment to the coast. Finally, on the Albanian coast, flat shapes return, coastlines of floodplains and lagoons. The Croatian coasts along the Adriatic Sea, therefore, constitute a rich environmental heritage, within a complex system of protected areas: they have a jagged outline, with 1200 islands, islets and rocks and with important contexts, such as the archipelago of Kornati (Dugi Otok), Mljet (Mljet), the Brijuni (Brioni) and the waterfalls of the Krka.

Croatia became a part of the European Union in July 2013 and, therefore, the Government began to align to European Directives for environmental protection. The final list of Nature 2000 Network sites is in the process of being adopted by the Croatian Government. The list 
will be sent to the European Commission together with the standard forms and maps. It is expected that the final list will contain more than 700 SCI proposals (174 of which will be caves) and 38 SPAS[20], thus putting Croatia, together with Slovenia and Bulgaria, on top of the standings among the countries with highest percentages of territory included in the Nature 2000 Network. Practically the whole of the coastline and the islands are being inserted within the Nature 2000 Network.

In addition, Albania is characterised by a rich biodiversity and a wide presence of ecosystems, which are untouched or only slightly affected by anthropic activity [21-22]. The Law no. 8906/2002 on protected areas [23] incorporated from previous initiatives many indications, regarding the protection and enhancement of natural resources.

Prior to 1990, Albania had a centralised economic system that managed to maintain a relative balance between rural and urban people. After 1990, the liberalisation of the economy produced a process of urbanisation and migration from the countryside to the city of proportions never known before. Movements of population from the countryside to the cities have led to a significant increase in the population centres in coastal urban with significant consequences on the environment. A number of animal species have begun to disappear, others have suffered a dangerous decrease in their number and others are at risk of extinction. Threats to the various natural ecosystems, especially forests and lagoon areas displace the local animal species by putting at risk the inherited natural balances. As a potential candidate country for accession to the European Union, Albania has undertaken to combat environmental degradation. The promotion of Nature 2000 Network in Albania might help the Albanian Government to align its environmental legislation with that of the European Union, as well as to create development opportunities for the local communities that live in rural areas.

\section{RESULTS}

The results of the study applied to the case of Croatia and in particular the case of the Neretva delta has been illustrated. It is particularly interesting because of the close relationship between the development of settlements and tourist activities along the coastlines and infrastructures. In fact, there are numerous processes involved in the evolution of land use caused by anthropic activities. In recent years the road networks, including roads and highways, have increased. This new network has connected very distant areas within each country and replaced the local roads that, in Croatia, followed the tortuous course of the coast and, in Albania, ran through the central part of the country, from North to South along the contours of the mountain territories.

Until 2000, the major Croatian infrastructures were built in the northern part of the country in order to connect the coast with the capital Zagreb and the latter with the rest of Eastern Europe. The motorway network, almost non-existent before 2000, is now completed in almost all the main directions. The A1 Motorway, also called Dalmatinska Autocesta, which runs nearly parallel to the coastline, connects Zagreb with Sibenik, Split up to Ploče constituting an important artery for the development of the Croatian coastal area. Moreover, new ports have infrastructures that have changed the profile of the coast. Croatia, really rich in islands, presents 56 marinas in service for recreational craft. The main ports are Zadar, Split and Dubrovnik, locations from which it is easy to reach the islands and the tourist coastal towns too. Other territorial transformation of coastal areas is due to agriculture that occupies large flat areas. At the same time, there are strong natural and landscape values [24-25]. The lower course of the Neretva River is a rare bio-ecological complex, as the result of centuries of natural modifications and more or less recent anthropic changes. The Neretva is the only river in the Region that opens into the sea with a delta mouth. At the same time the delta area 
presents the most intensive level of anthropic transformation. If in the past, the alluvial plain was known for malaria that systematically troubled the people, the improvements in the region over the last 30 years that have been undertaken using FAO funds have much improved the general conditions of life in the region. The Neretva river delta always attracts the attention of those who want to take advantage of its resources. It is evident that the different morphological modifications, introduced by human activities in the delta area, are expression of the different cultures which in time survived. However, the most significant transformation of this area appeared in recent decades, with a process of progressive reclamation aimed at protecting the region from flooding. An important aggression to the marshes was the drainage of the Modric Lake and of the entire lagoon. This modification caused the destruction of the habitat of many species of seabirds and migratory birds that used this area.

The lower valley of the Neretva River is still at risk from the further expansion of the port and the urban area of Ploče, as well as from vacation homes, industries and water pollution phenomena caused upstream by sewage from Mostar. The lower valley of the Neretva River is also subject to agricultural exploitation, but water drainage is less intense than in the past. However, the agrarian landscape integrates with the surrounding environment by providing the entire area a character strongly anthropiszed and for this it is different from the rest of the coast. The landscape of the Neretva delta is defined as the Green Pearl of the Croatian Southern Coast. In this paper we present the analyses carried out on the site of the Neretva Delta and especially the analysis of the land use related to different types of protected zones in this area (Fig. 4) and the analysis of agricultural use of the area set in the county plan (Fig. 5). In particular, Fig. 4 shows the analysis of the land use, through the Corine Land Cover data. This area is not a real protected area, although the establishment of the Neretva Delta Park was already proposed in 2003 and then again in 2007.

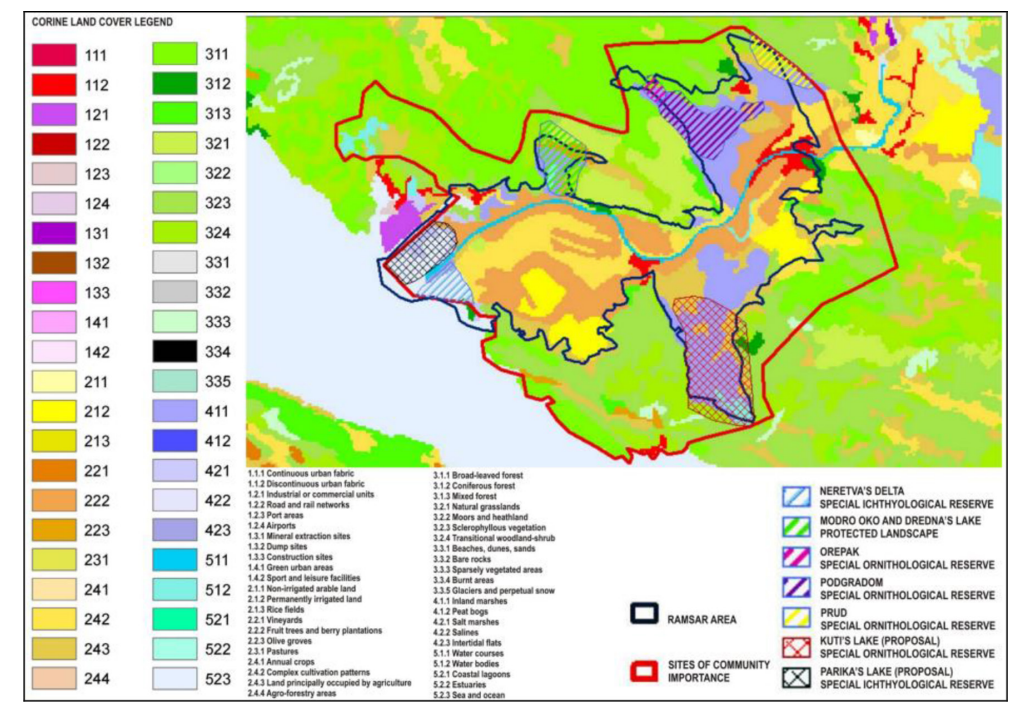

Figure 4: Land use Analysis of the Neretva's Delta area. Source: Corine Land Cover, Promotion of Networks and exchanges in countries of South Eastern Europe REReP 3.4.23, Processing in ArcGis by l.a.co.s.t.a. Lab. 


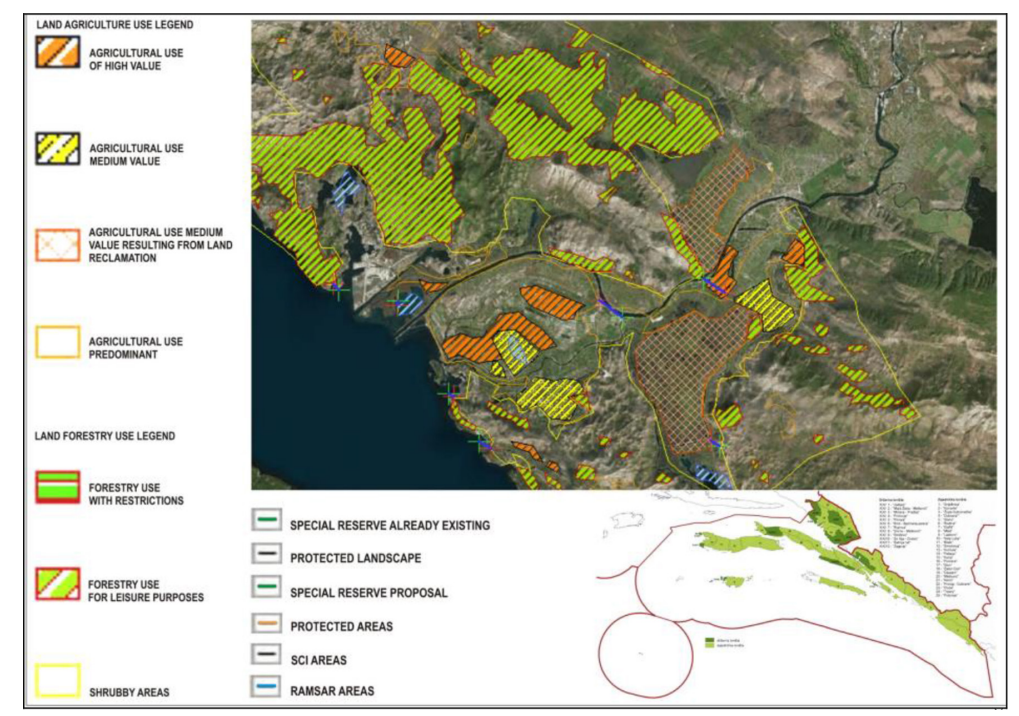

Figure 5: Norms in agricultural zones of the Neretva's Delta area. Source: Prostorni plan Županije Dubrovnik-Neretva, Processing in ArcGis by 1.a.co.s.t.a. Lab.

In our map, protected areas such as fish and bird reserves and protected landscapes are highlighted. This area was also included in the Ramsar List in 1993, with an extension of 12.742 ha and, finally, it was classified as a Site of Community Importance and inserted in the European Nature 2000 Network and, as such, it is pending approval and, therefore, its Management Plan.

The area is therefore affected by various types of protection, lacking a total and organic safeguard in the area. Because of its environmental peculiarity, the Dubronik-Neretva County Plan regulates its land use. Figure 5 shows, in fact, the requirements relating to the agricultural and forestry uses of the area under consideration, proposed by this plan, combining the environmental and landscape safeguards for a correct and sustainable land use. This area is of fundamental importance for agricultural production especially of fruit trees and citrus fruits. This production, which supplies all the national and international markets, is abundant because it arises from those territories that were subject to the land reclamation projects during the 1950 s.

\section{CONCLUSIONS}

Planning in coastal areas is certainly a central aspect of our study. In this paper a specific application regarding the case of the Neretva's Delta was illustrated, but the methodology was applied to other case studies. The most interesting considerations concern the comparison between the different situations in different countries, because the very different urban policies in place influence territorial assessments. Along the coastline areas, in fact, the most critical elements of the demographic and economic development of the involved regional contexts, converge. In the Molise case study, the region has experienced over the last three decades an intense construction activity, mainly concentrated in some municipalities: it highlights the existence of a real risk of a large-scale process of urbanisation of the Molise coast. 
A similar phenomenon is certainly sweeping the coastal landscape of Albania, in which there is, since the 1990s, the above mentioned process of urbanisation of the coastal strip, mainly concentrated in the vicinity of major urban areas, such as Durres and Vlora. Moreover, the methods of planning and the landscape of Croatia and Albania, having newly developed tools and recent laws, because of the troubled political history of these countries, present the benefit of having the spatial policy closely tied to the landscape policy.

The planning system in Albania began to be amended in the late 1990s, to adapt to the new political subdivisions and the decentralisation process that was started in those years. In response to the drastic changes in the use of the Albanian territory, the Albanian Government aims to address territorial development by implementing the concept of sustainable development considering all the components of the territory. The aim is not only to plan the sustainable development of the Albanian territory but also to decentralise some planning activities. In fact, it transfers the decision-making process for the drafting and approval of urban planning by the Central Government to Local Governments. In Croatia, issued new guidelines with respect to planning in the mid 1990s, which were later formulated as guidelines for the protection of the territory and the quality of the environment. Ten years later, in 2007, the first generation of laws on planning, the Law on Physical Planning and Construction Law was enacted, that governs the system of urban planning and the construction sector, the authority of State Power and Local Governments.

Another reason that prompted our research towards the deepening of a planning policy of Croatia was the Government's focus on the coastal areas, with the precise aim of containing urban sprawl along the coastline. The Croatian Government, in fact, strengthened the safeguards of the coastal heritage, extending the buffer zone of coastal and forcing counties to update their urban plans based on that law. The Plan of the Dubrovnik-Neretva County, in fact, has among its measures, the preservation and development of cultural, natural, historical and monumental and environmental, in addition to the conservation of marine resources. The plan identifies the landscapes to be protected and provides to extend the areas to be exploited, also including degraded areas and uninhabited islands, intended for tourist use and excluded from new construction projects. In conclusion, it was important to start from the most recent planning considerations in the Balkans Countries, while in Italy the inevitable temporal overlap of legislation has always separated the general planning from the planning oriented to landscape preservation. Therefore, the analysis of case studies identified in the Cross-border Countries is a contribution to the deepening of the relationship between spatial planning and landscape planning, as the urbanisation of coastal areas inevitably also affects the inner territories, invested from economic pressure issues related to tourism development that make the integrity of the environment and the landscape vulnerable in its more fragile contexts. Our methodology foresees the drawing up of a comparative and evaluation analysis for each of the resource systems, (that is, physical-environmental resource, landscape-visual resource, historic-cultural resource, productive-agricultural resource, demographic-tourism resource). Synthetic values emerge from the processing for each resources system, through the transformation of elementary data into indicators. For each resource system a final synthetic value was then calculated, which constitutes the orientation of the landscape quality aims for each territorial environment examined. Such landscape quality aims, according to the dictates of the new approaches are oriented to conservation, sustainable development and re-qualification, in order to achieve the evaluations targeted towards the search for landscape quality aims. 


\section{REFERENCES}

[1] Cialdea, D., Coastal zones along the Adriatic Sea. Italian and Cross-border experiences. WIT Transactions on the Built Environment, Vol 148, WIT Press, pp. 237-248, 2015.

[2] Cialdea, D., The Landscape features in the urban context. Sustainable strategies for the small town in the South of Italy. In Proceedings of the International Conference on Changing Cities II: Spatial, Design, Landscape \& Socioeconomic dimensions, ed. A. Gospodini. Grafima Publ.: Thessaloniki, pp. 169-179, 2015.

[3] Cialdea, D., Research Methodology. Territorial Survey Interreg Reports. Materials for Adriatic Cross Border Project. Report No. 1. GES.S.TER. Project/Interreg IIIA vol. 1, pp. 1-88, ArtiGRaficheLaregione, Campobasso, 2005.

[4] Cialdea, D., et al. Land Survey Materials. In Interreg Reports. Materials for Adriatic Cross Border Project Report No. 2 Land Use Evaluation. Analysis in the Different Landscape Performances GES.S.TER. Project/Interreg IIIA vol. 2 Chapter 4, pp. 173-177, ArtiGRaficheLaregione, Campobasso, 2006.

[5] Cialdea, D., et al. The GIS architecture elements for the coastal areas along the Adriatic Sea. In Proceedings of the 46th Congress of the European Regional Science Association, "Enlargement, Southern Europe \& the Mediterranean". PAPER NO. 348, Published on web wwwsre.wu-wien.ac.at /ERSA/ERSAC, 2006.

[6] Cialdea, D. \& Privitera, S., The state of the environment on the Adriatic coast: elements of value and conflict. In Proceedings of the 13th National Meeting of APDR University of Azores, Angra do Heroismo, Azores, Paper No. 241, Published on the web www. apdr.pt, 2007.

[7] Cialdea, D., Definition of Landscape Quality Aims and Ongoing Research. In Cialdea, D. Interreg Reports. Materials for Adriatic Cross Border Project Report No. 3. Environmental Assessment GES.S.TER Project/Interreg IIIA. vol. 3 Chapter 4, pp. 154-173, ArtiGRaficheLaregione, Campobasso, 2007.

[8] Cialdea, D., The study of Adriatic coastal areas: valorization hypothesis for sustainable development. In Proceedings 13th National Meeting of APDR University of Azores, Portugal, Paper n. 240, Published on the web www.apdr.pt, 2007.

[9] Ledio, A., Changing Planning Cultures- The Case of Albania. Radboud University: Nijmegen, 2012.

[10] Aliaj, B., Vulnerability in Albanian Cities, Dealing with Informality in Tirana. Vienna, European Urban Research Association/ EURA conference 2012.

[11] Ministria e Drejtësisë, Strategjia Ndërsektoriale. Reforma në fushën e të drejtave të pronësisë 2012-2020, Tirana: Ministria e Drejtësisë, 2012.

[12] Runko Luttenberger, L., Environmentally and Tourism-Friendly Urban Planning Model - The Case of Croatia, Tourism in Southern and Eastern Europe, pp. 387-394, 2013.

[13] Dumbović Bilušić, B., Landscape as a New Strategy for Spatial Planning in Croatia in 16th International CEMAT Symposium and 12th Council of Europe Meeting of the Workshops for the Implementation of the European Landscape Convention "Vision for the Future of Europe on Territorial Democracy," Thessaloniki, Greece, 2-3 October 2012.

[14] Dzelalija, M., Medunic-Orlic, G., Londo, A., Muda, V., \& Privitera, S., Environmental Values. In Cialdea, D. Interreg Reports. Materials for Adriatic Cross Border Project Report N. 2 Land Use Evaluation. Analysis in the Different Landscape Performances GES.S.TER. Project/Interreg IIIA, Campobasso:Arti Grafiche La Regione, pp. 100 134, 2006. 
[15] De Stefani, C., The two sides of the Adriatic Sea. Proceedings of the VIII Italian Geographical Congress, Florence, pp. 76-106, 1921.

[16] Almagiã, Who R., Sestini A., Trevisan L. (Edited by), Atlas of geographic types of the Military Geographic Institute, 2ND edition, Florence, I. G. M., 1948.

[17] Lanzafame G., Tortorici L., Geological Observations on the middle and lower basin of the Biferno River (Molise). Geol Roman, 1976.

[18] Go, I.P. (Ed), Anatomy of an Orogen: The Apennines and adjacent Mediterranean Sponsored, Kluver Academic Publishers, pp. 165-176, 2001.

[19] Vezzani, L., Ghisetti, F. \& Feast, A., Geological Map of the Molise. 1:100,000, Florence, SELCA, 2004.

[20] European Commission, Implementare le Direttive Habitat e Uccelli in Croazia, in Natura2000 Notiziario natura e biodiversità, no. 34, pp. 623-633, 2013.

[21] Dida, M., State of Forest Tree Genetic Resources in Albania. Forest Genetic Resources Working Papers, working Paper FGR/ 62E. Forest Resources Development Service, Forest Resources Division. FAO, Rome, 2003.

[22] Papayannis, T. \& Pritchard, D.E., Cultures and Wetlands in the Mediterranean: An Evolving Story, Athens, Med-INA, 2011.

[23] Albanian Law for Protected Areas N. 8906, 06 June 2002.

[24] Glamuzina, B.\& Glamuzina, M., Management of the Neretva River Estuary: Past and Future of a rich and fragile Natural Heritage, Naše Blackberries, no. 46 vol. 5-6, pp. 226-230, 2001.

[25] Conte Dubrovnik- Neretva, Prostorni plan Županije, Paper 1.3 Uvjeti Korištenja, Uređenja The Zaštite Prostora Područja Posebnih Uvjeta Korištenja ztaništa (Izvor Park podataka Županijski Zavod za prostorno uređenje Dubrovnik). 